\title{
Morphological Classification of Dysphemisms in Artistic Discourse
}

\author{
Olga N. Prokhorova, Olga V. Dekhnich, Elena S. Danilova, Vladislav A. \\ Kuchmistyy, Ekaterina F. Bekh \\ Belgorod State University, Russia
}

First published September 30, 2019

\begin{abstract}
:
Due to the wide-spread use of dysphemisms in contemporary speech, the topic of dysphemia has become extremely important. At the same time, research on this issue is clearly not sufficient to cover this phenomenon in full. This study pursued the following goal: to analyze the morphological features of dysphemisms within the framework of artistic discourse. The concept of dysphemism was described, and a classification of dysphemisms in contemporary linguistics was provided. Dysphemisms represented by different parts of speech were analyzed, enabling conclusions to be drawn about the features and frequency of dysphemism use. All results were illustrated with examples from artistic discourse. The research findings are summarized in the conclusion.
\end{abstract}

Keywords: artistic discourse, dysphemism, dysphemia, euphemism, classification

\section{INTRODUCTION}

The problem of dysphemia is extremely relevant in contemporary linguistics. It results from the fact that speech has been determined by various social norms, restrictions, and even legislative requirements for quite a long time. This has given rise to a widespread use of euphemisms in everyday communication, which has been carefully studied in contemporary science. However, linguists have not been interested in the reverse side of this phenomenon until recently. It was not until the phenomenon of dysphemia became clearly visible in all spheres of human life, that attention was paid to this problem.

There have been several attempts to classify dysphemisms according to various criteria, as well as to study the features of their functioning in different discourse types. We consider it promising to study dysphemisms through the example of artistic discourse, which is a reflection of all other types of discourse to a certain extent. In this article, dysphemisms in artistic discourse will be analyzed from a morphological point of view.

\section{METHODS}

The results presented in this article have been obtained using content analysis applied to works in the field of contemporary artistic discourse. Works by British authors have been used as research material. The purpose of using specific words or expressions in a context makes it possible to

(c) AesthetixMS 2019. This Open Access article is published under a Creative Commons Attribution Non-Commercial 4.0 International License (http://creativecommons.org/licenses/by-nc/4.o/), which permits non-commercial re-use, distribution, and reproduction in any medium, provided the original work is properly cited. For citation use the DOI. For commercial re-use, please contact editor@rupkatha.com. 
identify whether they are used as dysphemisms. Only the lexical units used purposefully have been chosen for analysis, instead of stylistically neutral synonyms used for creating a special effect. In addition, the comparative method has been employed in the historical and crosscultural aspect. In other words, the development of dysphemisms has been analyzed, and the approach to this phenomenon in Russian and Foreign Language Studies has been compared.

\section{RESULTS AND DISCUSSION}

Despite the fact that dysphemisms are wide-spread in the speech of contemporary people, this phenomenon has not been sufficiently studied in linguistics. For example, E.V. Shishova notes that the very word "dysphemism" apparently lacks the development of lexicographic characteristic development (Shishova, 2014). Most often, dysphemism is understood as the opposite of a euphemism, the opposite pole with a stylistically neutral concept, taken as a point of reference. Functional characteristics of dysphemisms enable to distinguish them from reduced vocabulary. Dysphemism is used deliberately to create a certain effect, which may consist in expressing attitudes toward an object or a phenomenon, as well as in creating conditions favorable for influencing an opponent.

However, if attempts to define dysphemism still make it possible to consider this concept from different aspects and to draw conclusions about its key features, the situation with the classification of dysphemisms is much more complicated. In studying this phenomenon, only a few classifications have been proposed. The approach of L.N. Mosievich described in the work "Dysphemisms and the Linguistic Picture of the World" seems of interest. The scholar attempted to analyze dysphemisms in English and Russian in terms of differences in the language picture of the world typical of the English and Russian speakers (Mosievich, 2010).

According to the author, the linguistic picture of the world has the most direct influence on the emergence and development of dysphemisms. Moreover, it is an immediate condition for their existence.

Based on the above, L.N. Mosievich identifies several semantic uses of dysphemisms in the language making it possible to provide a respective classification:

\section{Social status dysphemisms.}

This group includes the dysphemistic designation of various professions, social groups, ideologies, and so on. Let us give examples from the field of the artistic discourse.

So while Philip made tentative approaches to Elizabeth, families like the Raleighs, Grenvilles and Drakes put their shoulders to the door and pushed in the opposite direction. Thus, for a short interlude, the religion of the monarch could be said to be neither papist nor Protestant; and while it was safe to admit to either persuasion, it was wise to support neither too vigorously. Anthony Drew, the vicar of Polruan, was a good example of the effect such conflicts had upon the clergy. He was a big, bald man who had toed the papist line for the past few years under Mary, and was now willing to return to Anglicanism should that be the wish of his Bishop (Gidley, 1988).

\section{Dysphemisms denoting mental, psychological or social conditions.}

This group includes dysphemisms that characterize intellectual deficiencies, mental illness, and socially significant defects, such as addiction and the degradation following it. 
Christ, Arthur was no oil-painting, but he was like the Winged Victory compared with him!' And where does that place you in the beauty stakes? thought Pascoe. But what's it matter? Hell, in one day I've been jealous of a sour-faced moron like Dave Fernie and of a little tub of lard like Marcus Felstead! (Hill, 1987).

\section{Dysphemisms characterizing the biological characteristics of man.}

These include negative designations of gender, race, sexual orientation, nationality and other biological characteristics. Dysphemistic notations of homosexual orientation are used especially frequently in the English language.

'Everyone seems happy enough. I noticed that right off." Believe me, they are. Now back to business. You'll be taking over my job as cop winder, and when you do I'll be promoted to the looms, just as you'll be in time.' A female squealed, and then came up to them rubbing her backside.' That sod McAvoy got me again. Talk about wandering hands!' Natasha laughed.' You should be so lucky. With a face like mine I never get my bum pinched or felt! So don't complain!' (Blair, 1990).

The conclusion that dysphemisms serve as a linguistic indicator of the most acute social problems is especially interesting in the approach of L.N. Mosievich. Study of the dysphemisms prevailing at the moment may reveal the problems are currently most important for the society. It also explains why the lexical composition of the dysphemisms of the groups described above will be different in various languages.

The approach of A.N. Rezanova is considered to be the most comprehensive one. She proposes the following classification based on lexical-semantic classes:

1) dysphemisms denoting the concepts of "death", "disease", physical and mental disabilities. This is a vast area of use both for euphemisms and dysphemisms. This is easily explained taking into account the peculiarities of the human psyche. Death and disease are the most terrible phenomena for people, so in their speech they try either to smooth out the negative effect, or to ridicule and reduce their value with the help of dysphemisms.

Some examples of such dysphemisms may be found in the following contexts:

' He couldn't fu' ${ }^{* * * * *}$ handle it.' Paul checks the chops. OK.' He couldn't handle Mum, he couldn't handle me,' John says.' He is going to find out eventually.' Paul hates saying this, but it needs saying.' How's he going to feel then?" Maybe he'll pegout first,' John says (Neale, 1993).

I really do love this old place, Mandy had said. Mandy, who had blacked Tommy Bellinger's eye because he had called Charity a four-eyed freak. This application was wrong, but somehow it felt as if it would be a lot more wrong to turn Mandy in (Wilder, 1993).

2) dysphemisms related to criminal sphere;

This includes a wide range of vocabulary denoting different types of criminal activity, illegal professions, psychoactive substances. Most of these dysphemisms formed a long time ago, because the problem of crime and violation of the law has always excited the public. However, they have become wide-spread quite recently as a result of emancipation and the shifting of the cultural norm framework. Now there is a tendency to nominate things without embellishment.

'The guy with the gun? Yeah, but who was it? With a rat like Mahoney you can usually bet he's been rubbed out for business reasons. This time, that doesn't jell." Why not? All the cops know 
about Mahoney is that he worked for Joey Bonanza. I haven't noticed Bonanza issuing any monthly company reports.' (Chester, 1990).

3) dysphemisms denoting the flaws and vices in the character of people;

This section has much in common with the previous one, since it is flaws of character that lead to violations of the law and all sorts of addictions. However, in this case the focus is shifted from illegal activities directly to the human being.

'What trouble?" I told you. They're vicious. They're like a tribe. Anyone outside their immediate circle is suspect." Are you one of them?" God no. I've broken away from that whole junkie crowd. I'm doing that computer course in the spring. Some of the women resent me for it (Hall, 1993).

4) dysphemisms used for the designation of nationality;

This group of dysphemisms has expanded enormously lately due to increased attention to political correctness issues. The abundance of euphemisms and the negative reaction to the designations of many nationalities has caused the spread of dysphemia in this area as a balancing process.

Miss Jarman cut in: 'The girl and the blackamoor can go. We've no more use for them.' (Darke, 1989).

5) dysphemisms denoting God, the devil, words associated with various religious rituals, curses.

Dysphemisms of a religious group are used in a literary text in two cases. The first is to strengthen the statement to demonstrate the emotional state of the character. Most often it is panic, irritation, anger and other negative emotions. In the second case, dysphemisms are used to ridicule religion and everything connected with it. This subspecies include blasphemy.

'No. I have to go home,' said Lucy, as if torn.' Why?' said Jay wildly.' Why? Your damn son?" No, I have to be up early in the morning.' (Cooper, 1991).

As these classifications show, the morphological features of dysphemisms and their grammatical aspect have not been studied sufficiently. Morphological characteristics are important for understanding the essence of the dysphemia concept, so this article attempts to analyze dysphemisms represented by different parts of speech.

Nouns are replaced by dysphemisms more frequently than other parts of speech. This results from the fact that dysphemisms are mainly used to discredit or to reduce the significance of any phenomenon or object. It is logical to assume that nouns, both stylistically neutral and dysphemistic, are used most often for the designation of objects or phenomena (Allan, 2001).

As well as any noun, dysphemisms of this group can be represented by nominal and proper names. Among proper names, anthroponyms occupy a special place. This is either the name of a historical figure causing unpleasant associations, or a variation of the name itself.

'Is that what you're trying to do then? Take our kids away from us because you reckon you know what's good for them better than what we do? You're no better than a Hitler.' Startled, George turned his head to stare at a woman who was standing up somewhere in the middle of the tightpacked rows of the audience (Rayner, 1991).

In this example, an angry woman compares the character with Hitler, which undoubtedly serves as a dysphemism expressing her extremely negative attitude to his actions. 
The use of animal names as dysphemisms is also common. These are the so-called contextual dysphemisms, which means that these words will be stylistically neutral in another context.

'Here is Theodor Herzl. He is dead you know. Ja, only forty-four years. Nicht gut. Forty-four is not old.' He looked keenly at Bobby over his spectacles.' You are not forty-four?" No, I am not. I' ll be thirty-four on my next birthday." Ja? And you are not married.' Bobby closed his eyes.' No, I am not.' Fine you know I'm not, you old goat, thought Bobby. He wondered if Gebler was playing a game with him. (Cairney, 1991).

'Alain?' she said.' No, Nigel!' he replied with satisfaction. He felt a certain gratitude to Eleanor for giving him this idea.' Oh, it is you, you lying pig,' Gina screamed.' So, you have discovered my little secret!' She dropped the phone (Pitt-Kethley, 1991).

In the above examples, the names of two animals are used as dysphemisms expressing the speaker's dismissive attitude towards the objects of speech.

The sphere of dysphemisms opens a wide range of word-building possibilities. This can be explained by the fact that even the most dismissive word loses its emotional connotation with frequent use and is not perceived as offensive any more. At the same time, new and unexpected names may shock the interlocutor and produce the desired effect.

In English, a disparaging connotation can be transmitted by adding the following suffixes: -er, ster, -ard, -ling to a noun.

'What part do I ever play in any of your decisions?' Phoebe asked. If there was an answer, none was given. Jess wondered uncomfortably whether she was expected to move out of the way and let the old ditherer through, or side with the Law and her own interests. She didn't budge, but was slightly shaken by the trace of tears on Phoebe's sparse lashes (Darke, 1989).

Then, the same denial, but more flatly:' I don't believe you." He's been trying to speak to you to warn you. He hired this man, then changed his mind." How do you know all of this?' Again, the accusation.' He sent me to stop it." Hired you too?' It wasn't pleasant to hear it from her lips, but yes, he said, he was just another hireling. It was as though Estabrook had set two dogs on Judith's heels -- one bringing death, the other life -- and let fate decide which caught up with her first.' (Barker, 1992).

In this article the issue of structural features of dysphemisms will not be addressed, as this topic is very comprehensive. It is mentioned, however, that dysphemisms can be formed in the same ways as ordinary common nouns.

The next extensive group of dysphemisms includes adjectives. Their evaluative emotional function makes them ideal for dysphemization. Adjectives can be used in speech both as dysphemisms and in combination with dysphemistic nouns in order to enhance the latter.

He flailed for balance, snatched at the closest tablecloth and dragged a cascade of smashing china and chinking silver to the floor as he fell. There was a second's silence after the last shard of china had settled.' You shit-faced, yellow-bellied bastard,' Sharpe said to the sprawling Lord John (Cornwell, 1990).

In this example, in order to reinforce the dysphemism "bastard", the author uses as many as two dysphemistic adjectives: "shit-faced" instead of "drunk" and "yellow-bellied" instead of "coward".

She laughed and sipped her coffee -- this is wine, you see?' In the lounge, at first, we have had sherry and they have talked about -- cricket! With the first glass of wine and the mulligatawny 
soup -- you know, bouillon with curry powder? -- Major Mills is crumbling bread rolls and talking of his children: the sons at Oxford and now in the City. The daughter has finally made a good marriage, after a dodgy one (Cooper, 1993).

In this example, the adjective "dodgy" serves as a dysphemism in itself, giving a negative connotation to the previous marriage of the character.

The above examples reveal two clear trends. First, adjectives are used as independent dysphemisms, since this word itself has a reduced stylistic meaning. In the second case, adjectives function as contextual dysphemisms.

The verb is a very important part of speech. According to V.V. Vinogradov, "the semantic structure of the verb is more capacious or flexible than all other grammatical categories. The verb word, with richness and diversity of meanings, combines wealth and diversity of forms" (Vinogradov, 1972). Still, the use of verbs in the function of dysphemisms is not so common.

This use can be of two kinds. In the first case, deliberately rude words denote processes that were originally taboo in speech, such as sex, engaging in prostitution, drug use, criminal activity, natural needs. This can be seen in the following examples:

'Folly, are you all right? I'm sorry; I just didn't know... And all those things I said, I was just guessing really. I just gabble on -- I didn't mean --" It's not your fault,' Folly managed through her sobs.' You've done me a favor really. I'd rather know. At least -- I did know, sort of, but I couldn't help hoping..." I know what you mean.' Lisa sounded as if she did (Rees, 1992).

I felt very wicked taking them to a pawnbroker, and then I sent the money to Giulia. I knew my heart would break if he left me and she was threatening to come and find him! But now, it is things like that which make me ask: what is morality? Shall we snaffle some of Bernard's sherry? What do you think?' She dipped a couple of ratafias and crunched them, smiling.' (Cooper, 1993).

In these examples words "gabble" and "snaffle" used to emphasize the negative attitude to the senseless chat and stealing.

The second group of dysphemistic verbs are crude names of ordinary actions, such as eating, spending free time, and resting. In this case, the use of dysphemism often expresses a negative attitude not towards the action itself, but to the person or persons committing it. This can be illustrated with the following examples:

"Well, I have three children of my own now and I thought it would be nice to surprise them with the sugar mice on the tree, and also the chocolate cat." How many would you like?' Agnes watched the young, plump, matronly lady look at the young man, whom she imagined to be the same age as his wife. And when he said,' I would say a couple of dozen, because that little tribe just don't eat, they gobble. And who's to prevent the grown-ups enjoying a sugar mouse now and again. But will that spoil your window?'

Adverbs are rarely used as dysphemisms. Suffice it to consider the following examples:

But the goal - shedding light in a pigheadedly focused way - remains the same (Gidley, 1988).

Josh stared stupidly at the trooper and then scowled at Alex (Barker, 1992).

Whilst the authors of all these evils were idly and stupidly gazing on this menacing meteor, which darkened all their horizon, it suddenly burst, and poured down the whole of its contents upon the plains of the Carnatic." (Wilder, 1993). 
Adverbs in these cases are used either to characterize the verb or to specify adjectives. Thus, the use of dysphemistic adverbs is not different from the usual functions of adverbs.

Interjections as dysphemisms are quite common in the artistic discourse. Since this group of words is used to express an emotional attitude towards an object or a phenomenon, it is not surprising that they are often employed to express negative emotions. In addition, dysphemistic exclamations are characteristic of youth slang (Rawson, 1989).

She went the whole way now:' He'll pull the switch for the first television transmission to Danu, and that will also be the moment Danu is absorbed into the republic as the fifty-eighth province. The whole proceedings will be filmed here and transmitted simultaneously all over the archipelago." Holy shit!" I beg your pardon, Adolph?" Nothing, nonya, I was just surprised (Mo, 1991).

\section{CONCLUSION}

Due to the recent changes in political and social life, the speech behavior of people has become significantly loosened, and a tendency towards coarsening of speech has emerged. This could not but reflect in the sphere of the artistic discourse. An increasing number of authors go beyond the literary language, resorting to coarse and sharp expressions to enhance the emotional effect.

After analyzing the morphological features of dysphemisms used in the artistic discourse, the following conclusions can be drawn.

Dysphemisms can be expressed by any part of speech that has an independent meaning. The meaning component is most important, because dysphemisms are inherently synonymous with a negative connotation.

Most often nouns and adjectives are used in the role of dysphemisms. This is explained by the nominative function of the former and the descriptive function of the latter. Often a negative attitude towards an object or a phenomenon is expressed through the negative nomination of a particular process. In this case, the verb is used as a dysphemism.

Adverbs in the role of dysphemism are used in the same way as in ordinary speech. Most often they specify the verb.

Interjections are the extensive material for dysphemization. Their traditional role of enhancing expressiveness makes it extremely simple and logical to replace them with reduced vocabulary.

In general, the widespread dysphemia in all spheres of human life is worth noting. Only recently, such style of speech was only allowed in tabloid editions, but now it is perceived quite normally as an expressive means in works of literature. To enhance the effect, the authors resort to new techniques, use word-building methods actively and expand the boundaries of dysphemism use.

\section{REFERENCES}

Allan, K., Burridge, K. (2001). Euphemism and Dysphemism: Language Used As Shield and Weapon (1st Replica Books ed.). Bridgewater, N.J.: Replica Books.

Barker, C. (1992). Imajica. Glasgow: HarperCollins.

Blair, E. (1990). Maggie Jordan. London: Bantam (Corgi).

Cairney, J. (1991). Worlds apart. Edinburgh: Mainstream Pub. Ltd. 
Chester, P. (1990). Murder forestalled. UK: Chivers Press.

Cooper, F. (1991). Jay loves Lucy. London: Serpent's Tail.

Cooper, F. (1993). I believe in angels. London: Serpent's Tail.

Cornwell, B. (1990). Sharpe's Waterloo. UK: Collins.

Darke, M. (1989). The first of midnight. London: John Murray (Pubs) Ltd.

Gidley, Ch. (1988). Armada. London: Fontana Paperbacks.

Hall, A.L. (1993). Deliria. London: Serpent's Tail.

Hill, R. (1987). A clubbable woman: a Dalziel and Pascoe novel. London: Grafton Books.

Mo, T. (1991). The redundancy of courage. London: Chatto \& Windus Ltd.

Mosievich, L.N. (2010). Disfemizmy i yazykovaya kartina mira. Nauchnye zapiski, 3.

Neale, J. (1993). The Laughter of Heroes. London: Serpent's Tail.

Pitt-Kethley, F. (1991). Misfortunes of Nigel. P Owen.

Rawson, H. (1989). Wicked words: a treasury of curses, insults, put-downs, and other formerly unprintable terms from Anglo-Saxon times to the present (1st ed.). New York: Crown Publishers.

Rayner, C. (1991). The meddlers. London: Michael Joseph Ltd.

Rees, E. (1992). Hunter's harem. Richmond, Surrey: Mills \& Boon,

Shishova, E.V. (2014). Opredelenie termina disfemizm v lingvisticheskih terminologicheskih slovaryah, spravochnikah i ehnciklopediyah. Filologiya i kul'tura.

Vinogradov, V.V. (1972) Russkij yazyk. Grammaticheskoe uchenie o slove. M.: Vysshaya shkola

Wilder, Q. (1993) One shining summer. Richmond, Surrey: Mills \& Boon. 